\title{
Customer Loyalty towards Internet Banking in Nigeria
}

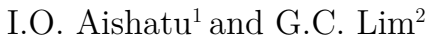 \\ ${ }^{1}$ Department of Economics ${ }^{1}$, Faculty of Economics and Management Universiti Putra Malaysia, 43400 Serdang, \\ Malaysia \\ ${ }^{2}$ Department of Business Administration², Faculty of Management, Universiti Teknologi Malaysia, 81310 Skudai \\ Johor, Malavsia \\ Email: m-gclim@utm.my
}

\begin{abstract}
Easy accessibility of information on banking activities has enabled customers to easily compare various bank products and thereby easily switch from one bank to another, resulting in diminishing customer loyalty. This results in retail banks continually working hard to make new innovations or improve their internet banking services in order to make their bank a better choice for the customer. Previous researches have shown that customer loyalty is essential for the survival and profitability of e-commerce. We investigate whether customers' trust, satisfaction, commitment, bank reputation, and the bank's website quality predict customer e-loyalty in a survey using structured questionnaire. Ordered logistic regression analysis was used to analyse the data. The results of the study revealed that bank reputation, satisfaction, trust, and commitment have a significant and positive impact on customer e-loyalty towards internet banking in Nigeria. However, website quality has a positive but insignificant influence on customer e-loyalty towards internet banking. The result further showed that reputation is an essential factor in building customer e-loyalty.
\end{abstract}

Keywords: E-loyalty, reputation, satisfaction, trust, commitment, website quality.

\section{Introduction}

The proliferation of and the advancement in internet-based technology has resulted in a fundamental change in how companies interact with their customers [1]. One such fundamental change is the wide adoption of internet banking by many banks. The internet seems an ideal means for carrying out banking activities due to its cost saving potentials and speed of information transmission, but with the internet becoming a near perfect market, information becomes instantaneous enabling online customer to compare and contrast products and services with minimal time, effort and expenditure, resulting in diminishing customer loyalty [2]. [3] noted that, in a rush to build internet businesses, it is a mistake to focus on attracting customers instead of retaining them since acquiring customers on the internet is expensive. Hence, unless those customers stick around and make repeat purchase over the years, profit will remain elusive [3]. Despite the appeal of internet banking, customer loyalty among internet banking consumers has become an issue as banks in Nigeria provide competing internet banking services. Although customer loyalty is crucial, most of the studies on internet banking in Nigeria focus more on internet banking adoption [4-7]. Therefore, the need for research on the factors responsible for keeping customers loyal towards internet banking providers in Nigeria has become crucial. Thus, for internet banking providers to survive in the ever evolving internet market environment, it is imperative for internet banking providers to understand those factors that will enable banks to build a strong relationship with their customers that will eventually lead to earning the loyalty of the customers. In line with the evolving situation, the objective of this study is to investigate factors that influence customer loyalty towards internet banking providers within the Nigerian context.

\section{Literature Review and Hypotheses Development}

\subsection{Internet Banking and Customer E-loyalty in Nigeria}

Technological breakthroughs and innovations in Information and Communications Technology (ICT) led 
to the emergence of e-banking services which in recent time has become globally popular. Internet banking reforms in the Nigerian banking system started in 2003 following the introduction of the guidelines of electronic banking by the Central Bank of Nigeria. Services provided by the internet banking providers mostly include checking of account balances and statements, submission for new accounts, credit cards and loans application, fixed deposits placement, funds transfer, bills payment, credit cards application, loans and insurance payment, request for cheque books and statements, check status or stop payment of cheques, application for bank drafts and telegraphic transfers, prepaid reload, investments trading, interest rates calculator, Foreign currency converters, and insurance policy renewal. According to [8] there is evidence of increasing growth of internet banking transactions in Nigeria, with the growth of electronic banking transactions rising from $73 \%$ in 2009, $85 \%$ in 2010 to $289 \%$ in 2011. Additionally, the Central Bank of Nigeria Annual Report (2011) showed an increasing trend in the volume and value of internet banking in Nigeria for the period 2006 - 2011. Prior to the deregulation and liberalization of the banking sector, the banking system was characterized by "arm chair banking". The deregulation, liberalization and the banking consolidation exercise, witnessed the emergence of fierce competition among the banks, where product offering is no longer a major competitive advantage [9], as virtually all the banks provide similar services. As such, (Akpan, 2009) emphasised that, to maximize profitability there is need to enhance repeated patronage by winning the loyalty of the customers. Additionally, Reichheld \& Schefter (2000), noted that, acquiring customers is enormously expensive, and unless customer sticks around and makes transactions, profit will remain elusive. Therefore for internet banking providers in Nigeria to survive in the ever evolving internet market environment, it is imperative for internet banking providers to understand those factors that will enable banks build a strong relationship with their customers that will eventually lead to earning the loyalty of the customers.

\subsection{Customer E-loyalty}

The importance of customer loyalty in e-commerce has been acknowledged by many scholars $[2,3]$. Customer loyalty is viewed as a repeated purchasing behaviour of a particular product or service. Customer e-loyalty is a concept within the branch of loyalty which is implemented in the e-commerce domain [10]. [11] defined e-loyalty as the willingness of the customer to maintain a stable relationship in the future and to engage in a repeat visits behaviour using the company's website as the first choice among alternatives. Given that competition in an online retail environment is just a click of a mouse away, enhancing e-loyalty, has become essential for the survival of online retailers [3].

\subsection{Trust}

In the absence of face to face contact, the most important factor for choosing and making repeat purchase from an online retailer is trust [12]. In addition, according to [13], trust is an important consideration in the development and fostering of e-commerce relationship. Trust is a feeling of security, based on the belief that one party's behaviour is guided by favourable intention towards the best interest of the other, and on the competence of a business to keep its promise [14]. Trust is also defined as the willingness of a party to be vulnerable to the action of another party based on the expectation that the other will perform a particular action important to the trustor, irrespective of being monitored or controlled by the other party [15]. In the context of e-retailing, trust is defined as belief or expectation that the e-retailer can keep promises and can be depended on [16]. Similarly, [17] defines trust as "the degree of confidence customers have in an online exchange". While in the context of internet banking, [10] view trust as assisting in removing perceptions related to risk and insecurity among online customers when engaging in online financial activities. [18] suggested that trust can be built through ensuring security, high quality services, keeping promise, showing respect to customers and fulfilling commitments. $[19,20]$ recognised trust as an important aspect in developing long-term customer relation. [21-23] concluded that there exists a positive and significant relationship between trust and customer loyalty. Thus, creating an enabling environment in which an organization or retailer gains the trust of the customer is a key to the success of online businesses. As such, the following hypothesis is proposed:

H1: Trust (T) has a positive influence on customers' e-loyalty towards internet banking in Nigeria. 


\subsection{Satisfaction}

According to [17], customer satisfaction is a key factor when creating customer loyalty, especially in the banking sector. [24] defined satisfaction as "an ex-post evaluation of buyer's experience with a service which results in a positive feeling, indifference, or a negative feeling". Additionally, [25] defined customer satisfaction as "an overall evaluation based on total purchase and consumption experience focused on perceived product or service performance compared with pre-purchase expectations over time". Thus, [26] concluded that satisfaction is essential for building and retaining a loyal base of a long-term relationship. Furthermore, [27] suggested that a dissatisfied customer is more likely to search for competitor offer than a satisfied customer. [14] identified the speed of delivery, competence, and friendliness of staff, reliability and responsiveness as factors that create satisfaction. The rule for creating satisfied customer is to meet or exceed customer satisfaction, creating customer delight and providing good customer service [28]. The role of satisfaction in building customer e-loyalty implies the positive effect that satisfaction has on continued activities in online transactions $[22,29,30]$. Therefore, with evidence showing that customer satisfaction eventually leads to e-loyalty, the following hypothesis is proposed:

H2: Customer satisfaction (CS) has a positive influence on customer e-loyalty towards internet banking in Nigeria.

\subsection{Reputation}

According to [31], corporate reputation is acknowledged as having the potential to impact on customer loyalty toward the firm, as customers are believed to be more loyal to the products of firms with a good reputation. [32] noted that, a firm's reputation is a critical asset in online retailing due to the inherent uncertainty associated with internet trading. Thus, online retailers with a favourable reputation will create a greater degree of loyalty [33]. Reputation or corporate reputation can be viewed as a mirror of the firm's history which serves to communicate to its target group information regarding the quality of its products or services in comparison with those of its competitors. [34] defines reputation as a representation of a company's past actions and future prospects that describe the firm's overall appeal to all of its key constituents when compared with other leading rivals. Prior studies [31] found that reputation has a significant impact on e-loyalty. Similarly, the good reputation of an online retailer or firm will go a long way towards attracting and retaining customers. In the context of loyalty to internet banking in Nigeria, the following hypothesis is proposed:

H3: Corporate reputation (CR) has a positive influence on customer e-loyalty towards internet banking in Nigeria.

\subsection{Commitment}

Customer commitment in the present competitive market is regarded as a vital key in marketing relationships. Commitment is defined as a consumer's conviction to maintain (rather than terminate) a relationship that might produce functional and emotional benefits [35]. Additionally [36] referred to Commitment as the willingness to develop and maintain a positive exchange relationship. Commitment has been defined as a customer's sense of belonging and involvement or association with the service provider [37, 38]. [39] defined commitment in an online environment as the intention to maintain a valued relationship with the website. Thus as suggested by [40], businesses need to earn their customers' commitment before they can expect to gain their loyalty. Previous studies [41 - 43] reveal that customer commitment in an online transaction significantly influences the development of customer loyalty. These findings led to the following hypothesis:

H4: Customer e-commitment (CC) has a positive influence on e-loyalty towards internet banking in Nigeria.

\subsection{Website Quality}

One of the characteristics of online consumer behaviour is the low cost of searching for alternatives, making customer loyalty harder to achieve in the online context than in the offline one [44]. As such Website with remarkable quality will unquestionably influence customers' willingness to maintain, deepen and broaden 
their relationship with the service provider [3]. Thus, measuring website quality enables firms to better understand its essential antecedents and consequences and, develop methods for improving quality to achieve competitive advantage and build customer loyalty [45]. Previous studies [46, 47, 44] revealed that customers' intention to revisit a website is significantly influenced by the quality of the website. Therefore, to discourage customers from switching to other competitors, internet banking providers need to continuously work at enhancing their website quality in order to gain higher customer loyalty. Hence the following hypothesis is proposed:

H5: Website quality has a positive influence on e-loyalty towards internet banking in Nigeria.

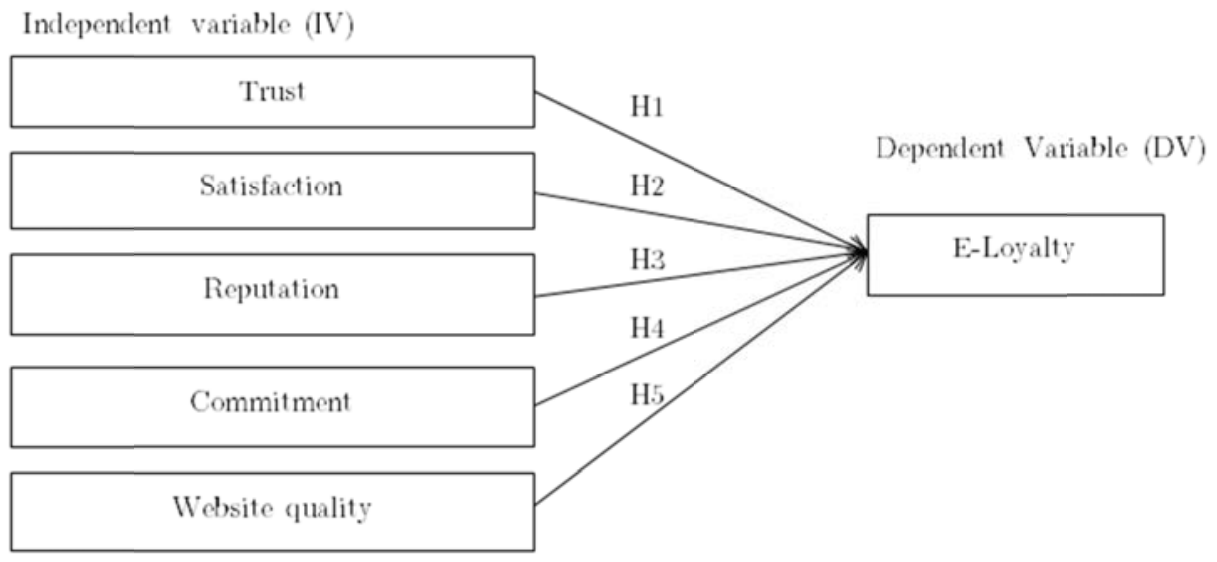

Figure 2.1 Conceptual framework

Based on the literature review, the conceptual framework of our study of factors influencing e-loyalty is depicted in figure 2.1. Customer e-loyalty to e-banking in Nigeria (the dependent variable) is determined by trust, customer satisfaction, reputation commitment and website quality, the dependent variables.

\section{Methodology}

\subsection{Sampling and Instrumentation}

Convenience sampling using an online self-administered Questionnaire was used for data collection with a planned sample size of 200 respondents. The online questionnaire (e-questionnaire) was developed using google drive, and subsequently, the link was mailed to respondents via their email address as well as various Nigerian online forums and chatrooms. The respondents for this study were mainly customers of First Bank, Guaranty Trust Bank, and Zenith and of various professions, educational background, with internet banking experience, residing within the Abuja metropolis. These banks were the front liner banks in the in Nigerian banking league in 2013 as well as the top three Nigerian banks as at 2013 [57, 58].

The questionnaire comprises of three sections. Section one enquired the respondents' internet banking experience, such as frequency of internet use, familiarity with internet banking, internet banking provider and frequency of internet banking use. The second section of the questionnaire enquired on those factors that influence the respondents' loyalty to their internet banking service providers. Customer e-loyalty, trust, customer satisfaction, reputation, and commitment were measured using 4 items each, while website quality was measured using 6 items. In order to maximize the measurement reliability with respect to constructs considered, all items used to measure the constructs in this study were adapted from previously validated instruments. The Items used were adopted from [48, 22, 33, 42, 38]. All the items were measured on a 5 point Likert scale ranging from 1 (strongly disagree) to 5 (strongly agree). Section three of the questionnaire enquired the respondents' demographic background including age, gender, occupation and educational background.

The questionnaire statements were kept short, precise and used clear unambiguous language so as to avoid confusion and to maintain the respondents' interest for the duration of the process of completing the survey. Prior to the actual administering of the questionnaire, the questionnaire was pre-tested in a pilot 
study among Nigerian students in Universiti Teknologi Malaysia (UTM), Johor Bahru, Malaysia, after which revision was made. Table 3.1 shows the various constructs and the items used to measure each construct.

Table 3.1: Construct and measurement items

\begin{tabular}{|c|c|}
\hline Constructs & Items \\
\hline \multirow[t]{4}{*}{ Trust $(\mathrm{T})$} & $\begin{array}{l}\text { I feel comfortable relying on my internet banking provider when I need to conduct } \\
\text { banking transactions. }\end{array}$ \\
\hline & Even if not monitored, I'd trust my internet banking provider to do the job right. \\
\hline & I am quite certain what to expect from my internet banking provider. \\
\hline & My internet banking provider will always act in my best interest. \\
\hline \multirow{4}{*}{$\begin{array}{l}\text { Customer Satisfaction } \\
\text { (CS) }\end{array}$} & I am fully satisfied with the services of my internet banking provider. \\
\hline & My internet banking provider always meets my expectation. \\
\hline & My experiences with my internet service provider are excellent. \\
\hline & $\begin{array}{l}\text { Overall, I am very satisfied with the way my internet banking provider carries out my } \\
\text { transactions. }\end{array}$ \\
\hline \multirow{4}{*}{$\begin{array}{l}\text { Corporate Reputation } \\
(\mathrm{CR})\end{array}$} & My internet banking provider has a good reputation. \\
\hline & My internet banking provider has a better reputation compared to other rivals. \\
\hline & My internet banking provider has a good reputation for offering quality services. \\
\hline & My internet banking provider has a good reputation for good customer relation. \\
\hline Commitment & I feel a sense of belonging to my internet banking provider. \\
\hline \multirow[t]{3}{*}{$(\mathrm{CC})$} & My relationship with my banking provider means a lot to me. \\
\hline & If my internet banking provider ceases to exist, it will be a loss for me. \\
\hline & I would turn a blind eye to minor mistakes made by my internet banking provider \\
\hline \multirow[t]{3}{*}{$\begin{array}{l}\text { Website quality } \\
\text { (WQ) }\end{array}$} & $\begin{array}{l}\text { Website design: } \\
\text { Operating my internet banking provider's website is easy for me. } \\
\text { The display pages within the website are easy to read. }\end{array}$ \\
\hline & $\begin{array}{l}\text { Website structure: } \\
\text { My internet banking provider's website loads quickly. } \\
\text { When I use the website there is very little waiting time between my actions and the } \\
\text { website's response. }\end{array}$ \\
\hline & $\begin{array}{l}\text { Website content: } \\
\text { My internet banking provider's website adequately meets my information needs. } \\
\text { It is easier to use the website to complete my internet banking transactions. }\end{array}$ \\
\hline \multirow{4}{*}{$\begin{array}{l}\text { E-Loyalty } \\
(\mathrm{CL})\end{array}$} & I will continue to carry out banking transaction with my internet banking provider. \\
\hline & I will recommend my internet banking provider to friends and acquaintances. \\
\hline & $\begin{array}{l}\text { I will consider my internet banking provider as the first choice whenever I want to } \\
\text { transact. }\end{array}$ \\
\hline & I intend to do more transaction with my internet banking provider in the future. \\
\hline
\end{tabular}

\subsection{Analytical Procedures}

This study employed the use of ordinal logistic regression using SPSS software version 22 (2013) for data analysis. Given that the dependent variable for the present study was ordered, measured on a Likert scale ranging from 1 (strongly disagree) to 5 (strongly agree), this implies that linear regression technique is not appropriate in this case. Hence, an ordered response model should be used instead [59].

\subsubsection{Ordinal Logistic Regression Model Specification}

$$
Y=f\left(Y^{*}\right)
$$




$$
Y^{*}=\alpha_{j}+\beta X_{i}+\varepsilon_{i}
$$

where:

$\mathrm{Y}$ is the observed ordinal variable. $\mathrm{Y}^{*}$ depicts unobserved latent dependent variable e-loyalty, which determines the level of the observed ordinal variable $\mathrm{Y}$

$i=$ index of respondents $(i=1,2,3, \ldots, \mathrm{n})$

$X_{i}=$ vector of independent variables for each respondent: Trust (T), Satisfaction (CS), Reputation (CR), Commitment (CC) and Website quality (WebQ).

$\beta=$ vector of logit coefficient of independent variable to be estimated by maximum likelihood estimation (MLE)

$\varepsilon_{i}=$ error term, which is assumed to be normally distributed with mean 0 and variance equals 1

$\alpha_{j}=\alpha_{j}$ is the threshold (intercept) values

The category that each respondent falls into is expressed as:

$$
Y=\left\{\begin{array}{c}
1 \text { if } y^{*} \leq \alpha_{1} \\
2 \text { if } \alpha_{1}<y^{*} \leq \alpha_{2} \\
3 \text { if } \alpha_{2}<y^{*} \leq \alpha_{3} \\
4 \text { if } \alpha_{3}<y^{*} \leq \alpha_{4} \\
5 \text { if } y^{*} \geq \alpha_{5}
\end{array}\right\}
$$

where $\mathrm{Y}=1,2,3,4,5$ (1=strongly disagree to $5=$ strongly agree).

Thus, the probability that any respondent belongs to any category is given by the probability that, the $a_{j}-1<y^{*} \leqslant a j$, where $j$ is the level of ordinal response and $j-1$ is the number of predictions made by the model. This is expressed as:

$$
\operatorname{Pr}\left[Y \leq j X_{1}, X_{2}, X_{2}, X_{4}, X_{4}\right]=\alpha j+\left(-\beta_{1} X_{1}-\beta_{2} X_{2}-\beta_{3} X_{3}-\beta_{4} X_{4}-\beta_{5} X_{5}\right)
$$

\section{Data Analysis}

\subsection{Questionnaire Response Rate and Respondents' Profile}

Of the 200 questionnaires distributed, a total of 190 were collected indicating a $95 \%$ return rate. Upon inspection of the returned questionnaires, 4 were excluded from further analysis due to incomplete response, leaving a total of 186 usable questionnaires indicating 93\% response rate. Out of the 186 usable questionnaires, 17 of the respondents indicated not being familiar with internet banking and were subsequently excluded. Hence a total of 169 questionnaires were used for the final analysis representing $85 \%$ of the total questionnaire distributed. About $70 \%$ of the respondents were male and $30 \%$ were female. The large majority of the respondents (79\%) were aged between 25-44, while those aged 18-24 and 45 and above, constituted $8 \%$ and $13 \%$, respectively. Among the respondents, $24 \%$ had less than one year experience, $45 \%$ had 1-3 years' experience and $31 \%$ had more than 3 years of internet banking.

In terms of descriptive analysis of the respondents' response to each of the constructs, a large majority of the respondents $(82 \%)$ claimed to have trust in their internet banking service providers, similarly, on average $87 \%$ of the respondents admitted being satisfied with the services provided. Furthermore, an overwhelmingly $92 \%$ of the respondents attested to the credibility of their internet banking service providers reputation, in terms of commitment $74 \%$ of the respondents indicated being committed to their internet banking service providers. More so, about $90 \%$ of the respondents attested to the website quality of their internet banking service providers and lastly, an overwhelmingly $93 \%$ indicated being loyal to their internet banking providers, suggesting a high degree of loyalty.

\subsection{Results and Discussion}

To ensure the reliability of the construct under investigation, the internal consistency method using Cronbach's alpha with a minimum acceptable value of 0.7 as suggested by [49] was adopted. However, a 
lower threshold could be used if the value falls between 0.6 and 0.7 [50]. The results indicate that the entire construct was reliable as the values of the Cronbach's alpha for the constructs range from 0.64 to 0.9 , thus, considered satisfactory for further analysis for the relationship between the independent variable and the dependent variable. The Cronbach alpha value for each construct is shown in table 4.1. Multicollinearity test was also conducted to ensure that no two or more of the independent variable used in the present study were highly correlated with each other. The result of the Tolerance and Variance inflation factor (VIF) test for multicollinearity as shown in Table 4.2 indicated a Tolerance value of more than .1 and VIF of less than 10 respectively for all the independent variable. According to [60], multicollinearity exists when the tolerance and VIF values for the independent variables are less than .1 and more than 10 respectively. Thus it can be concluded that the independent variables are not highly correlated with each other.

Table 4.1 Cronbach's alpha reliability test

\begin{tabular}{l|c|c}
\hline Variables & No. of items & Crocnbach's Alpha \\
\hline Trust & 4 & 0.728 \\
\hline Satisfaction & 4 & 0.908 \\
\hline Reputation & 4 & 0.866 \\
\hline Commitment & 4 & 0.636 \\
\hline Website Quality & 6 & 0.876 \\
\hline Customer e-loyalty & 4 & 0.860 \\
\hline
\end{tabular}

Table 4.2 Tolerance and VIF test for multicollinearity

\begin{tabular}{|c|c|c|}
\hline \multirow{2}{*}{ Variables } & \multicolumn{2}{|c|}{ Collinearity Statistics } \\
\hline & Tolerance & VIF \\
\hline Trust & .555 & 1.802 \\
\hline Satisfaction & .332 & 3.013 \\
\hline Reputation & .375 & 2.670 \\
\hline Commitment & .559 & 1.622 \\
\hline WEBQ & .611 & 1.637 \\
\hline \multicolumn{3}{|c|}{ a. Dependent Variable: Customer e-loyalty } \\
\hline
\end{tabular}

Ordered logistic regression analysis was conducted to determine whether the odds ranging from strongly disagree to strongly agree on the loyalty of the customer is influenced by trust, customer satisfaction, reputation, commitment, and website quality.

The chi-square $\left(\chi^{2}\right)$ statistic $(134.024, p=.000)$ indicates that the model gives a significant improvement over the baseline intercept-only model. This basically tells us that the model gives better predictions for the outcome categories. More so, the analysis indicated that overall the model fits the data as shown by the Pearson and Deviance chi-square in Table 4.2, where a large significant value indicates we have a good model ( $\mathrm{p}>.05$ ). The pseudo $\mathrm{R}^{2}$ shows that the model explains about $72 \%-83 \%$ (cox and snell .72; Negelkerke .83) variance in customer e-loyalty

Table 4.3 Goodness-of-Fit

\begin{tabular}{l|c|c|c}
\hline & Chi-Square & df & Sig. \\
\hline Pearson & 988.775 & 1879 & 1.000 \\
\hline Deviance & 447.189 & 1879 & 1.000 \\
\hline \multicolumn{2}{l}{ Link function: Logit. }
\end{tabular}

The parameter estimate and odd ratio $(\mathrm{OR})$ of the ordinal regression analysis as shown in table 4.3 reveal that, trust $(\mathrm{OR}=1.870)$ implies that, the odds of the customer being loyal to his/her internet banking provider increases by 1.870 for each unit increase in trust holding the effect of other independent 
variables constant. Similarly, satisfaction with an $\mathrm{OR}=2.893$ implies that, the odds of the internet banking customer to be loyal increase by 2.89 for a unit increase in their satisfaction given that the effect of other independent variables is held constant. Furthermore, the OR of reputation is 6.078, indicating that, the odds of customer being loyal to his/her internet banking provider increase by 6.078 for every unit increase in reputation holding the effect of other independent variables constant. More so, commitment $(\mathrm{OR}=1.539)$ implies that, the odds of the customer being loyal to his/her internet banking provider increase by 1.539 , indicating that, for each unit increase in commitment, the loyalty of the customer will increase by 1.539 after controlling for the effect of other independent variables. Thus, the study concluded that, increasing the trust the customers have toward their internet banking providers, providing satisfactory services, gaining their commitment and building a strong bank reputation enhances the loyalty of the customer towards their internet banking services providers within the Nigerian context. This conclusion is in accordance with previous findings $[10,29,17,23,53,33,43,42]$. In addition, the results reveal that the odd of a customer being loyal to his/her internet banking service providers is higher with the bank reputation as compared to customer satisfaction, trust, and commitment in the Nigerian context. This conclusion is consistent findings of [53] who found reputation to be an essential factor for encouraging customer loyalty towards Internet banking in Malaysia.

However, the odd of the customer being loyal as regards the website quality was found to insignificant. This indicates that quality of the website can be a necessary but not a sufficient condition towards gaining the loyalty of the internet banking customer. This is in line with a study carried out by [54]. A possible reason for the insignificant influence of website quality could be that experienced customers are already familiar with the website and can easily navigate around it. This is supported by [19, 55 and 56] in which the authors noted that website quality is an important factor impacting consumers' first-time transaction, but its effect diminishes with the accumulation of consumers' experience. This is evident with the high percentage of internet banking experience among respondents, where about $76 \%$ of the respondents have at least 1 year experience. This is not surprising as evident with the highly youthful respondent profile.

Table 4.4: Coefficient and significance of results

\begin{tabular}{l|c|c|c|c|c|c}
\hline Item name & Estimate & df & \multirow{2}{*}{ Sig. } & \multirow{2}{*}{ Estimate $\mathrm{b}$} & \multicolumn{2}{|c}{ 95\% Confidence Interval } \\
\cline { 6 - 7 } & & & & & Lower Bound & Upper Bound \\
\hline Constant 1 & 7.646 & 1 & .000 & & 5.974 & 9.319 \\
\hline Constant 2 & 12.034 & 1 & .000 & & 9.729 & 14.340 \\
\hline Constant 3 & 12.865 & 1 & .000 & & 10.385 & 15.344 \\
\hline Constant 4 & 15.860 & 1 & .000 & & 12.538 & 19.183 \\
\hline Trust & .626 & 1 & .033 & 1.870 & .273 & 1.035 \\
\hline Satisfaction & 1.062 & 1 & .006 & 2.893 & .304 & 1.819 \\
\hline Reputation & 1.805 & 1 & .000 & 6.078 & .994 & 2.616 \\
\hline Commitment & .431 & 1 & .041 & 1.539 & .297 & 1.260 \\
\hline Website Q & .347 & 1 & .244 & 1.415 & -.237 & .930 \\
\hline
\end{tabular}

\section{Conclusion}

The results from the data analyses revealed that, the odd of the internet banking customer being loyal towards their service providers increases with a unit increase in trust, satisfaction, reputation, and commitment. Through analysing the result further showed that, reputation has more influence on the odds of the customer to be loyal towards internet banking providers. Hence our results reaffirm the importance of reputation, trust, satisfaction, and commitment in ensuring and sustaining e-loyalty towards internet banking providers.

Therefore, this study recommends display of honesty and sincerity in dealing with customers' transaction and keeping to promises, quick response to customers' problems, as well as providing suggestion box to get customers' opinion on services provided. More so achievement of awards of credibility, providing information on corporate social responsibility and declaring annual financial status as well as acknowledging customer birthdays and consistency in service delivery can serve as prerequisites to win the 
loyalty of internet banking users. Although website quality exhibits an insignificant influence on e-loyalty towards internet banking it should not be totally ignored, as it is very essential for early users.

\section{References}

1. E.E., Ibrahim. "Customer perception of electronic service delivery in the UK retail banking sector". International Journal of Banking Marketing, vol. 24, no. 7, pp. 475-493. 2006.

2. S.S. Srinivasan, R. Anderson, and K. Ponnavolu. Customer loyalty in e- commerce: An exploration of its antecedents and consequences. Journal or Retailing, vol. 78, no. 1, pp. 41-50. 2002.

3. F.F. Reichheld and P. Schefter. "E-loyalty: your secret weapon on the web". Harvard Business Review, vol. 78, pp. 105-133. 2000.

4. C.K. Ayo, J.O. Adewoye, and A.A. Oni. "The State of e-Banking Implementation in Nigeria: A Post-Consolidation Review". Journal of Emerging Trends in Economics and Management Sciences, vol. 1, no. 1, pp. 37-45. 2010.

5. M.E. Auta. "E-banking in Developing Economy: Empirical Evidence from Nigeria". Journal of Applied uantitative Methods, vol. 5, no. 2. 2010.

6. R.O. Salawu and M.K. Salawu. "The emergence of internet banking in Nigeria: An appraisal", Information Technology Journal, vol. 6, no. 4, pp.490-496. 2007.

7. O.S. Oyewole, M. Abba, J.G. El-maude, and I.A. Arikpo. "E-banking and Bank Performance: Evidence from Nigeria". International Journal of Scientific Engineering and Technology, vol. 2, no. 8, pp. 766-771. 2013.

8. S. A. Ojeka, and O.A. Ikpefan. "Electronic Commerce, Automation and Online Banking in Nigeria: Challenges and Benefits". Available: http://www.iiuedu.eu/press/journals/sds/SDS_2011/BME_Article5.pdf. 2011.

9. S.A. Aminu. "Empirical investigation of the effect of relationship marketing on Banks' customer loyalty in Nigeria". Interdisciplinary Journal of contemporary Research in Business, vol. 4, no. 6. 2012.

10.M. A. Al-Agaga and M. N. Khalil. "Factors that influence E-loyalty of Internet banking users". International journal of electronic commerce studies, vol. 3, no. 2, pp. 297- 304. 2012.

11.E.Toufaily, L. Ricard, and J. Perrien. "Customer loyalty to a commercial website: Descriptive meta-analysis of the empirical literature and the proposal of an integrative model". Journal of Business Research, doi: 10.1016/j.jbusres.2012.05.011. 2012.

12.F.F. Reichheld, R.G. Markey Jr and C. Hopton. "E-Customer Loyalty - Applying the Traditional Rules of Business for Online Success". European Business Journal, vol. 12, no. 4, pp. 173-179. 2000.

13.A. Bryant and B. Colledge. "Trust in the Electronic Commerce BusinessRelationship". Journal of Electronic commerce research, vol. 3, no. 2, pp. 32-39. 2002.

14.B. Lewis and M. Soureli. "The antecedent of customer loyalty in retail Banking", Journal of consumer behaviour vol. 5, no. 1, pp. 15-31. 2006.

15.R.C. Mayer, J.H. Davis, and F.D. Schoorman. "An integrative model of organizational trust". Academy of Management review, vol. 20, pp. 709-734. 1995.

16.R. Amit and C. Zott. "Value creation in e-business". Strategic Management Journal, vol. 22, no. 6/7, pp. 493-520. 2001.

17.D. Ribbink, A.C.R. Van Reil, and V. Liljander. "Comfort your onlinecustomers: quality, trust and loyalty on the internet". Management Services Quality, vol. 14, no. 6, pp. 446-456. 2004.

18.N. Ndibusi. "Relationship Marketing and Customer loyalty". Marketing Intelligence and planning, vol. 25, no. 1, pp. 98-106. 2007.

19.D. H. McKnight and N. L. Chevany. "What trust means in E-commerce customer relationship: an interdisciplinary conceptual typology". International journal of electronic commerce vol. 2, pp. 35-59. 2002.

20.M.K.O. Lee and E. Turban. "A trust model for consumer internet shopping". International Journal of electronic commerce, vol. 6, pp. 75-91. 2001.

21.Y. Pan, S. Sheng, and F.T. Xie. "Antecedents of Customer Loyalty: An Empirical Synthesis and Re-examination". Journal of retailing and consumer services, vol. 19, pp. 150-158. 2012.

22.L. Yuan-shun. "A model of customer e-loyalty in online banking". Economics bulletin, vol. 29, no. 2, pp. 892-903. 2009. 
23.A. Floh and H. Treiblmaier. "What keeps the e-banking customer loyal? A multigroup analysis of the moderating role of consumer characteristics on e-loyalty in the financial service industry". Journal of Electronic Commerce Research, vol. 7, no. 2, pp. 97-110. 2006.

24.S. Devaraj, M. Fan, and R. Kohli. "Antecedents of B2C Channel Satisfaction And Preference: Validating E-Commerce Metrics". Information Systems Research, vol. 13, no. 3, pp. 316-333. 2002.

25.A. Beerli, J. Martin, and A. Quintana. "A model of customer loyalty in the Retail banking market". European Journal of marketing, vol. 38, no 1/2, pp. 253-275. 2004.

26.A. Bhattacherjee. "Understanding information system continuance: An Expectation-confirmation model". MIS Quarterly, vol. 25, no. 3, pp. 351-370. 2001.

27.R. E. Anderson and S. S. Srinivasan. "E-Satisfaction and E-Royalty: A Contingency framework". Psychology and Marketing 20(2): pp. 123-138. 2003.

28.T. Brain. "Four rules of customer satisfaction and building customer loyalty. Business success". Available: http://www.briantracy.com/blog/business-success/four-rules-customer-satisfaction-customer-loyalty. 2012.

29.M.I. Eid. "Determinant of e-commerce customer satisfaction, trust, and loyalty in Saudi Arabia". Journal of Electronic commerce Research, vol. 12, no. 1, pp. 78-93. 2011.

30.H. Lin and Y. Wang. "An examination of the determinant of customer loyaltyin mobile commerce context". Journal of information and management vol. 43, pp. 271-282. 2006.

31.N. Nguyen and G. Leblanc. "Corporate image and corporate reputation in customers' retention decisions in services". Journal of Retailing and Consumer services, vol. 8, no. 4, pp. 227-236. 2001.

32.F. Bensebaa. "The impact of strategic actions on the reputation building of e-Businesses". International Journal of Retail \& Distribution Management, vol. 32, no 6, pp. 286-301. 2004.

33.L. Casalo, C. Flavian, and M. Guinaliu. "The Role of Perceived Usability, Reputation, Satisfaction and Consumer Familiarity on the Website Loyalty Formation Process". Computers in Human Behaviour, vol. 24, no. 2, pp. 325-345. 2008.

34.C. J. Fombrun. Reputation: Realizing value from the corporate image. Boston, MA: Harvard Business School Press. 1996.

35.I. Geyskens, J-B.E.M. Steenkamp, L.K. Scheer, and N. Kumar. "The effect of trust and interdependence on relationship commitment: A trans-Atlantic study". International Journal of Research in Marketing, vol. 13, no. 4, pp. 303-317. 1996.

36.J. J. Wu, Y. H. Chen, and Y. S. Chung. "Trust factors influencing online community members: A study of transaction communities". Journal of Business Research, vol. 63, no. 9-10, pp. 1025-1032. 2009.

37.G. Fullerton. "How commitment both enables and undermines marketing Relationships". European Journal of Marketing, vol. 39, no. 11-12, pp. 1372-1388. 2005.

38.A. Mukherjee and P. Nath. "Role of electronic trust in online retailing: A re-examination of the commitment-trust theory". European Journal of Marketing, vol. 41 (9/10), pp. 1173-202. 2007.

39.C. H. Park and Y. G. Kim. "Identifying Key Factors Affecting Consumer Purchase behaviour in an online shopping context". International journal of retail and distribution management, vol. 31, no. 1, pp. 16-29. 2003.

40.D. Gilliland and D. Bello. "The two sides to attitudinal commitment: The effect of calculative and loyalty commitment on enforcement mechanisms in distribution channels". Journal of the Academy of Marketing Science, vol. 30, no. 1, pp. 24-43. 2002.

41.B. Cater and V. Zabkar. "Antecedents and consequences of commitment in Marketing research services: The client's perspective". Industrial Marketing Management, vol. 26, no. 3, pp. 245-54. 2008.

42.G. Walsh, T. Hennig-Thurau, K. Sassenberg, and D. Bornemann. "Does relationship quality matter in e-service? A comparison of online and offline retailing". Journal of Retailing and Consumer Services, vol. 17, pp. 130-142. 2010.

43.P. Ponirin and T. von der Heidt. "Modelling the complexity of e-loyalty: the role of e-value, e-trust, e-satisfaction and e-commitment". Proceedings of the Australian and New Zealand Marketing Academy (ANZMAC) Conference. 28-30 November, Edith Cowan University, Perth, WA. ISBN: 9780646563305.2011.

44.C. H. Liang, J. J.Chen, and W. F. Wang. "Does online relationship marketing enhance customer retention and cross-buying?" Service Industries Journal, 28(6): 769-787. 2008.

45.S. Ganapathy, C. Ranganathan, and Sankarannayanan. "Visualization Strategies and Tools for Enhancing Customer Relationship Management". Communications of the ACM, Vol. 47(11): 93-99. 2004. 
46.H.P. Lu and J. C.C. Lin. "Predicting customer behaviour in the market-space: A study of Rayport and Sviokla's framework". Information and Management, 40:1-10. 2002.

47.B. Billy, L. Rob, and W. Ivan. "Impact of website quality on customer satisfaction and purchase intention: Evidence from Chinese online visitors". International Journal of hospitality management, vol. 27, no. 3, pp. 391-402. 2008.

48.D. Gefen. "E-commerce: The Role of Familiarity and trust. Omega". The International journal of management science, vol. 28, no. 6, pp. 725-737. 2000.

49.J. Hair, R. Anderson, R. Tatham, and W. Black. Multivariate Data Analysis. (5th ed.). New York: Prentice Hall. 1998.

50.L.J. Cronbach, and R.J. Shavelson. "My Current Thoughts on Coefficient Alpha and Successor Procedures". Educational and Psychological Measurement, vol. 64, no. 3, pp. 391-418. 2004.

51.H. F. Kaiser (1974). "An index of factorial simplicity". Psychometrika, vol. 39, no. 1, pp. 31-36.

52.M. J. Sanzo, M. L. Santos, R. Vazquez, and L. I. Alvarez. "The effect of market orientation on buyer-seller relationship satisfaction", Industrial Marketing Management, 32(4), 327-345. 2003.

53.B. Y. Yee, and T. M. Faziharudean. "Factors Affecting Customer Loyalty of Using Internet Banking in Malaysia". Journal of Electronic Banking System. Article ID 592297. 2010.

54.Z. Tao, L. Yaobin, and W. Bin. "The Relative Importance of Website Design Quality and Service Quality in Determining Consumers' Online Repurchase Behavior". Information Systems Management, vol. 26, no. 4, pp. 327-337. 2009.

55.H. W. Kim, Y. Xu, and J. Koh. "A comparison of online trust building factors between potential customers and repeat customers". Journal of the Association for Information Systems, vol. 5, no. 10, pp. 392-420. 2004.

56.P. B. Lowry, A. Vance, G. Moody, B. Beckman, and A. Read. "Explaining and predicting the impact of branding alliances and web site quality on initial consumer trust of e-commerce web sites". Journal of Management Information Systems, 24(4):199-224. 2008.

57.J. A. Ogundina. "Nigerian Banks and Global Challenges: Further Evidence". Handbook on economics, finance and management outlook, ISBN 978-969-9347-14-6., 2013.

58.Vanguard. CBN designates eight Banks 'Too Big to Fail'. Vanguardngr.com. 12, NOVEMBER 2013.

59.Greene, W. H. (2003). Econometric analysis (5th Ed.). Upper Saddle River, NJ: Prentice Hall.

60.Ho, R. (2006), Handbook of Univariate and Multivariate Data Analysis and Interpretation with SPSS, New York: CRC Press, pp. 249. 